\title{
How Scandals Act as Catalysts of Fringe Stakeholders' Contentious Actions against Multinational Corporations
}

Thibault Daudigeos, Thomas Roulet, Bertrand Valiorgue

\begin{abstract}
In this article, we build on the stakeholder-politics literature to investigate how corporate scandals transform political contexts and give impetus to the contentious movements of fringe stakeholders against multinational corporations (MNCs). Based on Adut's scandal theory (2005), we flesh out three scandal-related processes that directly affect political-opportunity structures (POSs) and the generation of social movements against MNCs: convergence of contention towards a single target, publicisation of deviant practices, and contagion to other organisations. These processes reduce the obstacles to collective actions by fringe stakeholders by pushing corporate elites to be more sensitive to their claims, by decreasing MNCs' capability to repress contentious movements, by forcing the targeted MNCs to formalise a policy to monitor and eradicate the controversial practices and by helping fringe stakeholders find internal and external allies to support their claims. This conceptual model of scandals as catalysts of contentious actions contributes to a better understanding of stakeholder politics by unveiling the role of the political context in the coordination of fringe stakeholders.
\end{abstract}

Keywords: stakeholder politics, scandals, political-opportunity structures, multinational corporations, fringe stakeholders

Acknowledgement: We are grateful for the guidance and support of Associate Editor Frank de Bakker and our two reviewers for their valuable ideas and recommendations. 


\section{How Scandals Act as Catalysts of Fringe Stakeholders' Contentious Actions against Multinational Corporations}

The process of stakeholders mobilising against multinational corporations (MNCs) is generally studied as part of the stakeholder-politics stream of research. This literature examines how stakeholders develop political activities and implement contentious actions to push MNCs to reconsider their practices and to implement inclusive policies (Baron, 2001, 2003; De Bakker, Den Hond, King, \& Weber, 2013; Soule, 2012b). The ability of fringe stakeholders located in emerging countries (who present no immediate risk to the operation and survival of firms) to push MNCs to reconsider their practices depends on their capacity to organise themselves through the emergence of structured social movements to gain influence, attract resources and apply pressure at an international level (Soule, 2009, 2012b). This conceptualisation of fringe stakeholders' capabilities to contest MNCs rests on a super-agentic vision, and authors tend to neglect the political contexts in which social movements emerge (King, 2007; Rucht, 2004; Soule, 2009). Fringe stakeholders' contentious movements emerge under distinctive political contexts, and their success in forcing MNCs to adopt new practices is largely dependent on the support and resources that they receive from their political environments (Campbell, 2005; King, 2008; McAdam, Tarrow, \& Tilly, 2003; McDonnell, King, \& Soule, 2015; Soule, 2009; Van Wijk, Stam, Elfring, Zietsma, \& Den Hond, 2013).

By exposing the corrupt practices of MNCs in emerging countries to a large audience, corporate scandals appear to be turning points in fringe stakeholders' mobilisation and contentious actions as they affect the political context at various levels (Canales, 2010; McDonnell \& King, 2013) and trigger a scale shift in the contention by bringing the issues to the attention of actors at different levels (Mena \& Waeger, 2014). For instance, the Nike 
scandal in 1997 had many consequences not only for the firm but also for its supply chain, as their suppliers were also forced to adopt more socially responsible practices. It has also transformed the norms of the industry, especially regarding the issue of child labour. Since this much-publicised corporate scandal, several similar cases have hit the headlines - for example, Total and Unocal in Burma and (more recently) the Rana Plaza textile factory in Bangladesh (Comyns \& Franklin-Johnson, 2016). These corporate scandals - broadly viewed as exposing the public to transgressions by corporations as part of normal operations (Clemente, Durand, \& Porac, 2016) - always feature political struggles between MNCs and fringe stakeholders in emerging countries (workers, local residents and communities). Even though this political dynamic has been well captured through the notion of 'boomerang effects' (Den Hond \& De Bakker, 2012; Keck \& Sikkink, 1998; McAteer \& Pulver, 2009), the role of corporate scandals in the transformation of political contexts and the structuring of social movements has so far received scant attention in the stakeholder-politics literature (De Bakker \& Den Hond, 2008b; B. G. King, 2008; Soule, 2012a).

In this research, our aim is to develop conceptual tools to foster understanding of how corporate scandals affect the ability of fringe stakeholders to mobilise and contest the corrupt practices of MNCs. In particular, we theoretically inform the processes through which corporate scandals give momentum to fringe stakeholders' contentious movements by affecting political opportunity structures (POSs), which are defined as 'the dimensions of the political environment that provide incentives for people to undertake collective action by affecting their expectations for success or failure' (Mena \& Waeger, 2014; Soule, 2009; Tarrow, 1994, p. 85). Political opportunity structures are the conditions and the positive contexts needed for activists to raise their claims and make them impactful (Weber \& Waeger, 2017). Among others, we examine the impact of scandals on a specific form of POSs, corporate opportunity structures. Corporate POSs are the conditions that make specific firms 
attractive to activists and are likely to yield to the pressure of social movements (Briscoe, Chin, \& Hambrick, 2014; King, 2008; Soule, 2009). To understand the effect and the mechanisms triggered by scandals on corporate POSs, we rely on the work of Adut, who identified three key social processes associated with scandals: convergence of contention on a single target (Benford \& Snow, 2000; Schultz, Kleinnijenhuis, Oegema, Utz, \& Van Atteveldt, 2012), publicisation of deviant behaviours (Adut, 2005; Thompson, 2000), and organisational contagion (Adut, 2005; Hoque, Noe Cross, \& Kunkel, 2012). We propose that these processes reduce the obstacles to fringe stakeholders' contentious actions by modifying the political context to their advantage. In particular, our framework explains how scandals affect different dimensions of POSs, particularly corporate POSs, and push MNCs to reconsider their practices and relationships with fringe stakeholders. In concrete terms, corporate scandals affect the vulnerability of firms as they create convergence and push the targeted MNCs to be more open to the claims of their fringe stakeholders. Scandals also trigger scale shifts by bringing contention to a different level, whether it broadens the scope beyond the firm and its industry or national scope or whether it focuses on a more micro-level of analysis. In this sense, it helps fringe stakeholders to gather allies and political support, for example from nongovernmental organisations (NGOs), political elites and sometimes MNC employees. Finally, the processes of convergence, publicisation and contagion also reduce threats of repression for mobilised stakeholders. Our research enhances the understanding of stakeholder politics by introducing the role of corporate scandals and their effects on the political context to the structuring of stakeholders' contentious actions against MNCs. By bringing the processes associated with corporate scandals into the stakeholder politics literature, we also contribute to fleshing out the mechanisms through which scandals can affect stakeholder networks.

Our paper begins by discussing how social movements emerge among fringe stakeholders, building on the stakeholder-politics perspective. We underline how this 
perspective neglects the role of political contexts in explaining the emergence of collective mobilisation among fringe stakeholders. Next, we conceptualise how corporate scandals help to produce favourable POSs, particularly corporate POSs, and act as catalysts by facilitating fringe stakeholders' mobilisation and contentious actions. Finally, we discuss our contributions to the literature on stakeholder politics and POSs and delineate a research agenda to pave the way for future work on the effect of exogenous shocks on stakeholder politics.

\section{How Do Fringe Stakeholders Succeed in Mobilising against MNCs?}

The mobilisation of fringe stakeholders against MNCs is a difficult task, as these stakeholders have to overcome many obstacles. The stakeholder-politics literature has shed some light on these difficulties, but it tends to minimise the role of the political contexts in which contention movements unfold (De Bakker \& Den Hond, 2008a; 2008b). The contention movements of fringe stakeholders against MNCs cannot rest solely on the shoulders of political entrepreneurs who will exert political influence and engage in effective talks with the representatives of benevolent MNCs (McDonnell et al., 2015). The dynamics of contention movements against MNCs depend on political contexts, and exogenous circumstances can dramatically affect their chances of success (Dorobantu, Henisz, \& Nartey, 2017). To better understand the effect of corporate scandals on the ability of fringe stakeholders to mobilise, we first need to understand the nature of the obstacles they face to see how these obstacles can be alleviated by the reshuffling of POSs, particularly corporate POSs.

\section{Fringe Stakeholders and the Obstacles to Contention Action}

Companies in general and MNCs in particular, tend to be faced with two main categories of stakeholders: primary and fringe (Frooman, 1999). One characteristic of fringe stakeholders (Hart \& Sharma, 2004) is that they do not immediately endanger the operation 
and survival of the enterprise (Mitchell, Agle, \& Wood, 1997). As described by Mitchell et al. (1997, p. 875), fringe stakeholders are 'those with urgent claims and having neither power nor legitimacy. They are the "mosquitoes buzzing in the ears" of managers: irksome but not dangerous, bothersome but not warranting more than passing management attention, if any at all.' Fringe stakeholders involve very weak resource dependency. Therefore, firms have less interest in integrating their expectations (Berman, Phillips, \& Wicks, 2005; Eesley \& Lenox, 2006). These stakeholders have no contractual relationship, which makes using legal procedures for obtaining reparation much more complicated (Clarkson, 1995; Vasi \& King, 2012). They are also characterised by their geographical, cultural and political remoteness from the MNC's headquarters and a lack of coordinated political support (Jensen \& Sandström, 2011; Keck \& Sikkink, 1998; Smith, Chatfield, \& Pagnucco, 1997; Tarrow, 2005). Therefore, this category of stakeholders tends to struggle to influence MNCs and to push them for more responsible practices (Den Hond \& De Bakker, 2012).

When they want to contest the practices of MNCs, fringe stakeholders face the wellknown dilemma of 'collective action' (King, 2008): even if they may collectively gain from acting together, they may individually perceive strong obstacles to doing so and be reluctant to move forward. In his foundational opus, The Logic of Collective Action, Olson (2009/1965) explains that individual actors will not necessarily participate in a collective effort, even if they are in the majority, because they expect to either still benefit from the rest of the majority taking action or to be too isolated to succeed. In addition, the lack of a shared identity makes individual actors more likely to see their problems as personal rather than collective (King, 2008). Recent work at the intersection of stakeholder politics and social-movement theory has shed some light on this issue and has identified various obstacles that fringe stakeholders must overcome to gain political influence over MNCs and to force them to address their grievances (Den Hond, 2009; Den Hond \& De Bakker, 2007; King, 2008; Rowley \& Moldoveanu, 2003). 
Pluralistic ignorance and absence of shared experience. Without a sense of shared experience and grievance, individual actors may perceive their own problems in isolation from those of other actors and not look for collective solutions (King, 2008). Fringe stakeholders may suffer from what has been described as 'pluralistic ignorance' (Clemente \& Roulet, 2015). Despite privately rejecting the MNC's transgression, each may incorrectly assume that most others accept it and therefore go along with it. Accordingly, any collective action should be structured around a common identity (Rowley \& Moldoveanu, 2003), and fringe stakeholders have to know each other and share a common set of values and beliefs (Den Hond \& De Bakker, 2007). This shared identity will serve as a basis for deciding which tactics and repertoires of actions will be used to win and maintain influence over MNCs and force them to take into consideration the expectations of fringe stakeholders (Zietsma \& Winn, 2008). The more widely the stakeholders are scattered, the more complicated it becomes to coordinate their common identity and to define tactics and repertoires of actions against MNCs (Bruijn \& Whiteman, 2010). Only publicised deviance can trigger the formation of a mnemonic community and collective memory of a firm's misconduct (Mena et al. 2016).

Threats of repression. With no guarantee that a movement will be successful, individual commitment to a contention movement against MNCs may be considered risky, especially if stakeholders are weak and dispersed. Powerful actors such as MNCs can punish fringe stakeholders for their participation in contentious actions with physical, economic, social or symbolic sanctions (Yu, 2009; Briscoe et al., 2014). This threat of repression pushes fringe stakeholders to accept the status quo and considerably limits the emergence of a movement of contention.

Lack of resources. Collective mobilisation also requires many resources to collect and share information, coordinate efforts with other stakeholders, and bargain with MNCs 
regarding acceptable behaviours and compensations. Fringe stakeholders need to have access to tangible resources (financial capacities, subsidies, offices, electronic devices, and artefacts enabling contention) for organising and succeeding in their contentious actions (Jenkins \& Perrow, 1977). Without these resources, no contention movement will emerge because fringe stakeholders will be unable to define and enforce actions against MNCs.

The more isolated and dispersed the fringe stakeholders are, the more acute is the dilemma of collective action (Olson, 2009/1965) as they face an absence of shared identity, need important resources to coordinate themselves, and are exposed to threats of repression. These obstacles that fringe stakeholders face must be addressed by their representatives, who act as key political entrepreneurs and intermediaries between stakeholders, international institutions and MNCs (Banerjee, 2011; Della Porta \& Tarrow, 2005; Georgallis, 2016; Keck \& Sikkink, 1998; Tarrow, 2005). These political representatives reduce the uncertainty and costs of individual involvement by collecting and aggregating individual claims so that no single individual bears the social and economic costs of participation (Soule, 2012a), thus contributing to overcoming pluralistic ignorance. They succeed in crafting shared understandings that legitimise collective and contentious actions (McAdam, McCarthy, \& Zald, 1996). They connect multiple efforts and initiatives at local and transnational levels and create a structured social movement (Kraemer, Whiteman, \& Banerjee, 2013) with stronger resource endowment and in which individual actors are less likely to be repressed because of the dilution of responsibility. These political entrepreneurs frame collective identities, structure the movement, identify targets, define tactics, and gain the support of international institutions (Den Hond \& De Bakker, 2007; King \& Pearce, 2010; Yaziji \& Doh, 2013).

\section{Stakeholders' Contentious Action and POSs}


Although recent studies on stakeholder politics have provided a nuanced account of the role of stakeholders' representatives in mobilising fringe stakeholders, the same studies may also appear overly optimistic regarding their ability to help stakeholders with diluted interests and identities to overcome the dramatic obstacles they face (Jordan \& Van Tuijl, 2000; Khan, Munir, \& Willmott, 2007). The solution offered in the literature relies on a superagentic vision of stakeholder politics, as political entrepreneurs will bring sufficient levels of coordination and resources, prevent the repression endeavours of powerful MNCs, and develop a shared identity among scattered stakeholders. Following the recent call by scholars to integrate political contexts into our understanding of social movements (Campbell, 2005; King, 2008; Kriesi, 2004; McDonnell et al., 2015; Soule, 2009, 2012a, 2012b), we offer to flesh out an additional explanation to predict the emergence and success of fringe stakeholders' mobilisations against MNCs: that is, POSs (Mena \& Palazzo, 2012; Mena \& Waeger, 2014; Soule, 2012b), particularly corporate POSs (King, 2008; Soule, 2009; Briscoe et al., 2014; Weber \& Waeger, 2017).

Since the seminal work of Eisinger (1973), an increasing amount of literature on social movements has made use of the concept of the POS (Eisinger, 1973; Kriesi, 2004; Mena \& Waeger, 2014; Tarrow, 2005; Tilly \& Tarrow, 2006), which refers to the configuration of the political context in which a social movement arises. This determines not only the immediate outcomes of a social movement but also its development and potential influence over time; as Meyer underscores, 'activists do not choose goals, strategies and tactics in a vacuum. Rather, the political context sets the grievances around which activists mobilize, advantaging some claims and disadvantaging others' (Meyer, 2004, pp. 127-128). The emergence and success of a social movement are linked not only to its internal characteristics but also to the political context in which it unfolds (Davis, Morrill, Rao, \& Soule, 2008; Mena \& Waeger, 2014; 
Soule, 2009). Internal aspects of social movements and political contexts are intertwined and lead to success or failure in stakeholder mobilisation (Soule, 2009).

Tarrow gives a consensual definition of the POS that is widely used in the literature: 'consistent - but not necessarily formal or permanent - dimensions of the political environment that provide incentives for people to undertake collective action by affecting their expectations for success or failure' (Tarrow, 1994, p. 85). POSs reveal the 'focal points toward which activist groups deploy most of their time and resources, how and why they might move from one focal point to another (scale shift), and how a particular focal point's characteristics impact on activists' (Mena \& Waeger, 2014, pp. 1097-1098). POS researchers have worked on the main focal points or components of the political environment that social movements will face: corporate, industry, national and international POSs (Soule, 2009, 2012a). Social movements can foster scale shift, or in other words, move or expand contention from one stage to another and face different opportunity structures at multiple levels. For example, contention can be taken from the corporate level to the transnational scene, from the corporate to the industry level, from the national level to the international level, and from emerging countries to headquarters of multinationals in the developed world, and contention can be taken inversely in these relationships, as well. This is what Den Hond \& De Bakker (2012) call the boomerang effect (see also McAteer \& Pulvar, 2009) or the idea that corporate irresponsibility can be taken to different levels and with different targets to compel change.

As documented by Mena and Waeger (2014), social-movement scholars have characterised the main dimensions of the POS in terms of openness, presence of allies (McAdam et al., 1996), capacity and probability of repression (Tarrow, 1998), and outcomes implementation. They have linked these dimensions to the emergence and success of 
stakeholders' mobilisations (Van Der Heijden, 2006). Table 1 presents the main dimensions of POSs that allow characterisation of the political contexts in which social movements unfold.

\section{INSERT TABLE 1 ABOUT HERE}

The wisdom, creativity, structuring and outcomes of fringe stakeholders (their agency) can be understood and evaluated only by examining the political context (the structures) in which those choices are made. Even if they bypass obstacles and frame their actions efficiently, fringe stakeholders can face closed political arenas at firm, national and international levels - or unresponsive elites who will not consider their claims (Rucht, 2004; Soule, 2012b). They might also be exposed to repressive actors who try to sanction and punish their political mobilisation (Banerjee, 2011; Böhm, Spicer, \& Fleming, 2008). The political contexts and internal features of fringe stakeholders' movements are intertwined and must be considered together in the study of fringe stakeholders' contentious actions against MNCs (Campbell, 2005; King, 2008; Soule, 2012a).

Among the structures in the political contexts that fringe stakeholders face, social movement scholars have recently underscored the importance and centrality of corporate POSs. This level is acknowledged as a key focus of analysis of political opportunity structures and social movement dynamics (Weber \& Waeger, 2017). Corporate POSs consist of the features of a case (a firm and the context in which it evolves) that make it more likely to be won by activists (King, 2008). POSs at the firm level determine the expectations for success or failure of a contentious movement directed against the firm. They are defined by the dimensions of the interface between the firm and its environment. While corporations are usually 'seen as generally relatively settled internally and closed to outside influence' (Weber \& Waeger, 2017: 14), social movements may have windows of opportunities to influence them. For instance, corporations with higher reputation and presenting themselves as socially 
responsible are also more likely to yield to stakeholders and are perceived as more 'vulnerable' (McDonnell \& King, 2013; Zhang \& Luo. 2013). To fully understand and conceptualise corporate POSs, the dimensions of political opportunity structures can be applied to the corporate level of analysis. Weber \& Waeger (2017) put forward the openness of organisations, ideology, the presence of internal support as key determinants of their sensitivity to outsiders' demands and pressures. With regards to openness, firms with a collectivist identity are, for example, expected to be more open to stakeholders' claims and integrate outsiders in their decision-making process. In regard to ideology as an important aspect of corporate POSs, existing research has examined the CEO's ideology, with more liberal CEOs creating the conditions for activists to be successful when targeting these firms (Briscoe et al., 2014). Internal allies within companies can also play crucial roles to open the corporate political opportunity structure to outsiders, for example via organisational processes supporting whistleblowing (Briscoe \& Gupta, 2016). In their review, Briscoe \& Gupta (2016) note that activism within organisations is an important bridge between outsiders' claims and organisational decision making. In addition to the aspects noted by Weber \& Waeger (2017), other existing dimensions of POSs from Table 1 can be used to better understand the features of POSs at the corporate level. In addition, firms might have implementation procedures that enable outsiders to monitor progress and act upon them. Table 2 presents those different dimensions of POSs applied to corporate POSs with practical illustrations.

\section{INSERT TABLE 2 ABOUT HERE}

If recent works have documented the importance and main features of corporate POS, they have not examined the dynamic of organisational vulnerability, particularly the conditions that make some organisations and their support more vulnerable and sensitive to stakeholders' claims. This is important because corporate POSs are strongly influenced by 
opportunity structures at other levels of analysis and can thus evolve dramatically with time. For example, the openness to minority shareholders is favoured by some regulatory frameworks which can be pushed forward by activists. Expanding on Mena and Waeger's (2014) dimensions of the POS, we propose in this research to describe how corporate scandals: (1) transform POSs, particularly corporate POSs, and (2) make MNCs and their representatives more sensitive and responsive to fringe stakeholders' claims.

\section{Corporate scandals as Disrupting and Structuring Events}

Scandals have been recognised as potentially triggering events by many organisation theorists (Clemente et al., 2017; Graffin, Bundy, Porac, Wade, \& Quinn, 2013) and more specifically by social-movement scholars (Canales, 2010; Cottle, 2006; McDonnell \& King, 2013). However, while the importance of scandals is acknowledged, we lack clear theoretical understandings of their potential effects on political contexts and social-movement structuring. We do not know how they can - as exogenous shocks - dramatically affect POSs in general and corporate POS in particular (i.e., by making organisations more or less sensitive and responsive to stakeholders' claims). In this section, we mobilise relevant works on scandals to delineate how these major social events transform political contexts and impact fringe stakeholders' social movements against MNCs.

\section{The Conceptualisation of Scandal in the Social Sciences and Management Studies}

Scandals are ubiquitous phenomena in mediatised societies (Adut, 2005, 2008; Alexander, 1989; Thompson, 2000); they have received significant attention from sociologists (Thompson, 2000), political scientists (Entman, 2012) and media scholars (Kepplinger, Geiss, \& Siebert, 2012; Poerksen \& Detel, 2014; Shah, Watts, Domke, \& Fan, 2002). Scandals are broadly defined as the public exposure of a transgression of norms of a social actor (Entman, 2012). The sociologist John Thompson (2000) stressed the role of scandals in transforming a 
small-scale issue into a broadly known matter. Modern scandals are conceptualised as transcending physical and temporal boundaries because information can diffuse faster via a wider range of interconnected media (Poerksen \& Detel, 2014).

In comparison with the situation in other social sciences, the role of a scandal is less central in organisational studies (Clemente et al., 2016) but has been more specifically studied in conjunction with social movements (Tarrow, 1994). Most studies in organisation and management research concur in defining a scandal as the publicisation of a transgression $-\mathrm{a}$ deviance from social norms - that provokes collective disapproval among the public (Canales, 2010; Graffin et al., 2013). In the case of MNCs, corporate scandal can be considered as a process that starts with an incidence of misconduct and leads to the public stigmatisation of the offender, but not necessarily to punishment (Jackson et al., 2014). In addition, this stigmatisation often contaminates other parties, making scandal a pervasive social process (Jensen, 2006; Jonsson, Greve, \& Fujiwara-Greve, 2009; Pontikes, Negro, \& Rao, 2010). In the organisation-studies literature, only a limited amount of work has examined scandals as comprehensive processes. Instead, there are long-standing research traditions investigating isolated elements of scandals, especially in the social-movement literature.

Social-movement research has defined the key role of scandals as exogenous shocks that can shake up political contexts and make firms more or less targetable by activists. In this stream of literature, scandals are usually associated with a range of activities pushing the firms to act: boycotts (McDonnell \& King, 2013), protests (Yue, Rao \& Ingram, 2013) or online campaigns (Zhang \& Luo, 2013). Scandals can have a greater or lesser effect on corporate POSs - and thus on the mobilisation of stakeholders - depending on the severity of the reputational threat (McDonnell \& King, 2013), and they can specifically focus on one firm, thus intensifying the pressure on this target to react (Zhang \& Luo, 2013). Scandals can 
also affect the entrance of new competitors by exposing how reactive they must be to activists to deflect reputational threats (Yue et al., 2013). Finally, scandals can help social movements build shared identity and operate without defined leadership (Sutherland, Land \& Böhm, 2014).

Beyond the social-movement literature, some heterogeneous works focus on the antecedents of scandals. One lively stream of research examines organisational misconduct, wrongdoing and deviance from societal norms (i.e., transgressions) (Greve, Palmer, \& Pozner, 2010; Palmer, 2012), but it does not necessarily go so far as to consider scandals as potential consequences of those behaviours. A second stream of research examines the attention of those social-control agents and determines what makes a case of deviance visible to an audience (Bundy, Shropshire, \& Buchholtz, 2013). In this respect, two points have been scrutinised more specifically: the pressures and abnormal visibility of high social status (Graffin et al., 2013) and the dynamics of media attention (Thompson, 2000; Wiesenfeld, Wurthmann, \& Hambrick, 2008). At the other end of the spectrum, some works aim to understand the consequences of scandals in terms of organisational performance (Davidson, Worrell, \& Lee, 1994), stigmas (Hudson, 2008) or punishments (Coffee, 1981). However, very few conceptualise scandals as forming part of broader social dynamics that influence and are influenced by social actors in a recursive manner (Clemente et al., 2017); this is in contrast to the situation in other disciplines, such as sociology (Sass \& Crosbie, 2013) and political science (Thompson, 2000).

Processes Associated with Scandals: Convergence, Publicisation and Contagion

Building on the work of various authors in sociology (Entman, 2012; Thompson, 2000), Adut offers a large and comprehensive view on scandal processes and considers these disruptive events as part of a broader whole (Adut, 2005, 2008, 2012; Canales, 2010). This 
theoretical perspective can clarify how scandals affect corporate POSs and give momentum to the mobilisation of fringe stakeholders against MNCs. In his theory of scandals, Adut identifies three different but complementary processes that are at play: convergence of contention towards a single target, publicisation of deviant behaviours, and contagion to other social actors. These processes shed new light on our understanding of how a scandal may disrupt corporate POSs and help to structure stakeholders' contention movements against MNCs.

Process 1: convergence of contention towards a single target. One of the first effects of scandals is to simplify the causes of the social disorder (Adut, 2005, 2008; Girard, 1987; Thompson, 2000). Scandals contribute to assigning the entire responsibility and blame to a stigmatised person or institution, suggesting an easy and radical solution to the problem by calling for the punishment and banishment of one alleged culprit (Girard \& Freccero, 1986). This oversimplification of the cause-effect relationship contributes to concentrating critics and contentious actions on a single actor, who becomes a scapegoat accused of being at the origins of the social disorder (Girard, Gifford, \& Dupuy, 2006; Daudigeos, Pasquier \& Valiorgue, 2014). In the case of fringe stakeholders who contest the practices of MNCs, the convergence of the blame on a single firm through a corporate scandal has three impacts on the corporate POS.

A corporate scandal directly affects the sensitivity of CEOs to the claims of fringe stakeholders, as they are directly and personally blamed for the irresponsible practices implemented by their firms. Through a corporate scandal, CEOs become aware of irresponsible practices and are made accountable. They are compelled to act because of the risk of punishment by the industry, the government or the regulators. A good example of how corporate scandals impact the sensitivity and ideology of CEOs (Briscoe et al., 2014) is the 
case of Nike's sweatshops (McDonnell et al., 2015). Phil Knight was unresponsive and insensitive to concerns related to labour conditions until the end of the 1990s. When the scandal started, he was made accountable for child labour in Nike's supplier factories and was forced to consider this issue. In other words, corporate scandals allow fringe stakeholders to gain more access to the corporate polity, since the CEO becomes aware of their existence and is forced to attend to their claims (Ocasio, 1997):

Proposition 1a: Corporate scandals, via the process of convergence on a single target, make CEOs of targeted MNCs personally accountable for malfeasant practices and push them to reconsider their ideologies.

For the same reasons, this process of convergence and scapegoating has another effect on the corporate POS, as it affects the presence of allies for contending actors. Inside the targeted firm, managers and employees become more sensitive to fringe stakeholders' claims as they fear reputation damages and retaliation measures (Daudigeos, 2013; Den Hond \& De Bakker, 2012; Roulet, 2017). Some of them strive to find a way to circumscribe the effects of the scandal by supporting contending actors' claims in decision-making processes (Briscoe et al., 2014). More generally the convergence makes internal actors aware of the contention and thus more likely to support outsiders' causes.

Proposition 1b: A scandal, via the process of convergence on a single target, increases the presence of internal support by raising managers' and employees' awareness of fringe stakeholders' claims.

In addition, the convergence on a single target increases the presence of allies for fringe stakeholders among external stakeholders. Convergence enables uncoordinated social movements to target a specific malfeasant practice of the stigmatised MNC, thus facilitating the coordination of the various NGOs involved in the emergence of fringe stakeholders' 
contention movements (Glenn \& Mendelson, 2002; Jordan \& Van Tuij1, 2000; Kraemer et al., 2013). This directly relates to the process of scale shift through which activists bring the contention to a different level, enlarging the scope of the scandal or focusing it to trigger action (Den Hond \& De Bakker, 2012) but invariably leading to the gathering of a broader set of stakeholders and political supports. Commenting on the Nike case, McDonnell et al. (2015) stress the vagueness of social-movement claims before the 1990s. In the 1990s, however, activists began targeting more specific practices - such as wages below the legal minimum and child labour - which helped social movements unite around a well-identified cause. ${ }^{1}$ Through the convergence process, scandals accelerate the alignment of powerful NGOs' strategic agendas with grass-roots claims (Schultz et al., 2012). Fringe stakeholders gain access to national and international support that brings them resources, reinforces their public audiences, and provides access to decision-making processes (Edwards \& McCarthy, 2004). The process of convergence tends to connect stakeholders, bring new and sometimes powerful actors into the conflict, and create coalitions of allies that support fringe-stakeholder fights against the targeted MNC (Edwards \& McCarthy, 2004; Schultz et al., 2012). In the case of the Rana Plaza disaster, for instance, the international scandal brought multiple parties together to defend garment-workers' rights. These fringe stakeholders were able to find political support not only among traditional well-established labour unions but also among renowned consumption-based social movements that had access to decision-making processes at the MNC level (Reinecke \& Donaghey, 2015):

Proposition 1c: A scandal, through the process of convergence on a single target, creates a coalition of political allies that brings support and resources to fringe stakeholders against the targeted MNC.

\footnotetext{
${ }^{1}$ http://www.businessinsider.com/how-nike-solved-its-sweatshop-problem-2013-5?IR=T
} 
Process 2: Publicisation of deviant practices. A second social process associated with scandals is to make public the irresponsible behaviours and practices of an individual or organisation and to move it from the private to the public domain. While the acts of the guilty party may already be known to local actors, bringing them into the public domain makes these transgressions apparent and known to all. There is, as Adut (2005) describes, a disruptive publicity of social-norms transgression, and a change from private to public knowledge of the problem, particularly fostered by new forms of media (Poerksen \& Detel, 2014). Scandals take the form of rituals through which modern societies assert their core values by publicly marking certain individuals, organisations and behaviours as deviant. In this sense, scandals are moments when a society confronts the shortcomings and transgressions of its members and - by working through the sometimes-painful process of disclosure, denunciation and retribution - ultimately reinforces the norms, conventions and institutions that constitute social order (Adut, 2008; Alexander, 1989; Girard et al., 2006; Thompson, 2000). In the case of fringe stakeholders' mobilisation, corporate scandals publicise an MNC's malfeasant practices in emerging countries and transform the political context. Conflicts between fringe stakeholders and the MNCs stop being local and private, and they become public issues involving society. The targeted MNC appears as a social offender that has transgressed core social values. It is reviled and publicly accused of being at the origins of unacceptable transgressions.

This publicisation of the MNC's malfeasant practices has two impacts on the corporate POS. First, it affects the ability of an MNC to repress activists not only within the firm's scope but also more broadly to sanction fringe stakeholders. Publicisation contributes to changing the political context by reducing the threat of repression that MNCs can use to break fringe stakeholders' mobilisation (Banerjee, 2011). When an MNC's deviant practices are made publicly known through scandals, it becomes more difficult for it to repress fringe 
stakeholders, since this would put its image and legitimacy at risk (McDonnell \& King, 2013):

Proposition 2a: A corporate scandal, via the publicisation of deviant practices, reduces the targeted MNC's ability to repress fringe stakeholders' contentious actions.

Second, publicisation increases the scrutiny of the firm's activities in the longer term, particularly its ability to implement the activists' and contentious stakeholders' agenda. Scandals tend to accommodate inclusive policies and monitoring devices and to push MNCs towards greater accountability (McDonnell et al., 2015). Indeed, once the deviant practices are publicised, they enter into the collective memory (Herepath \& Kitchener, 2016) or 'the ways a community may perceive and reconstruct the past to meet its present needs' (Mena et al. 2016: 721). In fact, Mena et al. (2016) detail how corporate irresponsibility leads to the gathering of a mnemonic community and a common recollection of the deviance by stakeholders. When the public are aware of a deviance, pressures will be maintained on the deviant actors until they yield to those pressures (Clemente \& Roulet, 2015). As the Nike scandal gained traction in the media, the firm began imposing controls and audits by creating new standards for suppliers. The collective memory of corporate irresponsibility can be directly affected by the firm's effort to influence the stakeholders' perception of its transgression (Mena, et al. 2016). The corporate scandal thus creates a stronger capacity to enforce and monitor the decisions that the targeted firm makes to address fringe stakeholders' claims:

Proposition 2b: A corporate scandal, via the publicisation of deviant practices, makes the targeted MNC publicly accountable and forces it to formalise a policy to monitor and eradicate such practices. 
Process 3: contagion and change in political support. Adut notes that scandals taint not only the offenders but also the actors directly related and linked to them (Adut, 2008). Offenders' allies are contaminated and accused of being responsible for the transgression of social norms (Adut, 2005). In the same vein, other works underline potential contamination through association with the transgressor, or through the polluting nature of the transgression itself (Jensen, 2006; Jonsson et al., 2009; Pontikes et al., 2010). The publicity received by the deviant practices has negative and disruptive effects on parties other than the offender or immediate victim of the transgression. Following Adut, organisation theorists see scandals as historic events that brutally impact and transform social structures (Clemente, et al. 2017). A scandal generates structural changes of an unanticipated magnitude, and consequences that modify political contexts at least temporarily. For the actor judged to be responsible for the transgression, the scandal breaks alliances and access to resources. In the case of a corporate scandal, the contagion process impacts the resources, attitudes and support of the targeted MNC. A scandal taints not only the incriminated firm but also organisations and institutions directly associated with it. This process of contagion has two impacts on the corporate POS.

First, during a corporate scandal, the MNC's main customers or suppliers are affected by the public stigmatisation of deviant behaviours and then are forced to justify their past solidarity with the deviant practices (Briscoe, Gupta, \& Anner, 2015). The threat of contagion pushes the MNC's former allies to examine fringe stakeholders' claims to avoid courtesy stigma (Roulet, 2015; Shymko \& Roulet, 2017). External stakeholders and business partners that have built proximity with the targeted MNC might contribute to pushing the activists' agenda but are also more likely to be heard. For example, some executives at a higher echelon can acknowledge the concern and push for change (Briscoe et al., 2014). The target MNC loses political support, at least temporarily, while fringe stakeholders gain the understanding of elites in various organisations and institutions surrounding the MNC: 
Proposition 3a: A scandal, via the process of contagion, breaks the MNC's former alliances and increases the presence of potential allies supporting fringe stakeholders' claims.

Second, because the contagion process isolates the targeted MNC, repression is less likely as the MNC can count on less support to enforce sanctions against contending stakeholders. Indeed, as the MNC's allies start to defect to avoid courtesy stigma and the contagion of the scandal, they are less likely to be involved in the MNC's retaliation effort, in an effort to preserve their own reputation. Thus, the contagion effect decreases the overall threat of repression because it isolates the MNC in its repression efforts. The work of Siddiqui and Uddin on the Rana Plaza incident shows how MNCs have been protected for a long time by the Bangladeshi State and by local authorities who took charge of repressive actions against labour unions and NGOs. These repressive activities ended when the scandal arose (Siddiqui \& Uddin, 2016):

Proposition 3b: A scandal, via the process of contagion, reduces the targeted MNC's ability to repress activists as the allies of the targeted MNC are more likely to defect.

\section{Discussion}

In this article, we aimed to complement the stakeholder politics stream of research by asking how corporate scandals contribute to invigorating fringe stakeholders' contention movements against MNCs. We have advanced that POSs, as defined by social-movement scholars, offer a beneficial perspective on how scandals affect the contention movements of fringe stakeholders against MNCs (Fligstein \& McAdam, 2011; McAdam et al., 2003). Building on the sociology of scandals and Adut's work, we show how corporate scandals contribute to modifying corporate POSs and give momentum to fringe stakeholders' contention movements. We have identified three social processes associated with scandals that 
directly affect POSs - particularly corporate POSs - and the structuring of social movements: convergence of contention towards a single target, publicisation of deviant practices, and contagion to other organisations. These key processes transform political contexts and can be considered as catalysts that give considerable impetus to fringe stakeholders' contention movements. In this discussion, we elaborate on how corporate scandals and the ensuing changes in corporate POSs alleviate the obstacles to mobilisation faced by fringe stakeholders. We also show how our theoretical explanation has broader implications for the stakeholder-politics literature and provides opportunities for future research.

Alleviating the Obstacles to Mobilisation and Softening the Super-Agentic Vision of Stakeholder Politics

As shown in the first section, fringe stakeholders face three main barriers in their attempts to force MNCs to reconsider their practices: pluralistic ignorance, fear of repression, and lack of resources (De Bakker et al., 2013; Rowley \& Moldoveanu, 2003; Soule, 2012b). The stakeholder politics research stream has largely recognised these barriers as a consequence of the problem of collective action (Olson, 2009/1965) and has documented how stakeholders can succeed in bypassing them through the presence of representatives and political entrepreneurs. However, stakeholders' actions should not be studied in isolation, and scholars have recently claimed that such actions can be understood and evaluated only by examining the political context in which the actions take place (Campbell, 2005; King, 2008; Soule, 2012a). A corporate scandal directly impacts and facilitates the action of fringe stakeholders' representatives by creating favourable corporate POSs and helps to reduce barriers to their collective action.

The convergence on a single target and its associated simplified framing of the political context has a direct impact on fringe stakeholders' capacity to organise and contest 
the malfeasant practices of MNCs (Bartley \& Child, 2014; Soule, 2009, 2012b). The stigmatised corporation serves to support the stabilisation and harmonisation of repertoires of actions and contentious actions (De Bakker \& Den Hond, 2008a; Yaziji \& Doh, 2013) and concentrates the fringe stakeholders' scant resources. This simplification process gives rise to a simplified vision of the problem that is comprehensible and easier to share among fringe stakeholders (Kepplinger et al., 2012). The simplified rationale and oversimplification of the situation reduce the pluralistic ignorance phenomena and the absence of shared experience, as various scattered and uncoordinated fringe stakeholders realise they are victims of the malfeasant practices of the same corporation. Scandals help fringe stakeholders develop a shared experience and a common sense of fate. Moreover, the presence of allies also helps to connect fringe stakeholders with better-resourced organisations and supports greater achievements with fewer resources. Increased access to the decision-making process at the corporate level offsets fringe stakeholders' lack of resources as the targeted MNC is more sensitive to fringe stakeholders' claims.

Moreover, through the process of publicisation, a scandal tends to affect activists' perception of the possibility of success in achieving their endeavours to contest the MNC's practices (De Bakker et al., 2013; King, 2008). Fringe stakeholders are made aware of other actors being mobilised and sensitive to their claims and are thus more likely to join what then appears to be a political fight that is less risky, as it is supported by a majority (Clemente \& Roulet, 2015). Additionally, the threat of repression decreases, since the targeted MNC faces strong public support in favour of the social movement. The publicisation of the MNC's deviant practices makes fringe stakeholders more confident and more willing to take part in the contention movement. 
The contagion process also reduces mobilisation barriers, since it directly decreases the targeted firms' capacity to repress its opponents. Contagion profoundly transforms the social structure of the field by affecting the distribution of resources. The breaking of former alliances first deprives the MNC of material, symbolic and political support. At the same time, it attracts new resources to encourage collective mobilisation through increasing the presence of allies in favour of the contending actors.

\section{Complementing the Scale Shift Perspective}

Our scandal perspective on stakeholder politics also sheds new light on the conditions under which fringe stakeholders realise a scale shift - that is, 'a change in the number and level of coordinated contentious actions leading to broader contention involving a wider range of actors and bridging their claims and identities' (McAdam et al., 2003, p. 331). When a scale shift occurs, the fringe stakeholders' contention movement is no longer private and locally situated, but it becomes international through the building and involvement of a network of allies (Soule, 2013). International contention is more likely to harm firms, considering there is variance in how damaging scandals can be across the countries in which the firm is active (Den Hond \& De Bakker, 2012). Inversely, a scale shift - as a change in the level of contention - might take an industry-level, international or national issue to the corporate level and push internal actors to act upon their deviant practices.

Recent studies in social-movement theory underline the difficulty of realising a scale shift, mainly due to the divergence of interests and political agendas between network constituencies (Givan, Roberts, \& Soule, 2010). Other works note conflicts between local stakeholders and international NGOs that may thwart and hinder structuring and framing processes at the grass-roots level (Rodrigues, 2011). There may also be competition between the various local stakeholders to be heard and supported by the international NGOs. 
International NGOs usually consider only some of the many local claims that arise and, as Jordan and Van Tuijl (2000) note, successful and equitable cases of cooperation and interaction in transnational campaigns are the exception rather than the rule (Jordan \& Van Tuijl, 2000). All these recent findings further emphasise the contribution of scandals to align heterogeneous parties and to give momentum to a movement that may be hindered by local dissension.

As we have previously described, corporate scandals move the contention from the local to the MNC level, or corporate polity level. More precisely, one of the direct effects of scandals on the political context is to accelerate the alignment of the strategic agendas of the NGOs with grass-roots claims. It also tends to attract new NGOs that are sensitive to stakeholders' claims and to contribute to building a stronger advocacy network. Fringe stakeholders gain access to national and international support that brings them resources and access to public international audiences. This is reinforced by the appearance of new allies among political elites who fear contagion and do not want to be stigmatised as along with the incriminated MNC.

Avenues for Research

The identification of the three processes by which scandals give an impetus to fringe stakeholders' contentious actions and transform political contexts leads to intriguing questions and provides opportunities for further research on the link between corporate scandals and stakeholder politics.

The process of convergence towards a single actor and the simplification of the situation is a key phenomenon directly involved in the reduction of the obstacles faced by fringe stakeholders. This process of convergence is oriented towards an organisation that is perceived as entirely responsible for the social disorder; this organisational culprit becomes 
the specific target of the social movement (Bundy \& Pfarrer, 2015). It would be of particular interest to understand why some actors are held more responsible than others. Some actors, especially Western MNCs, appear to be the perfect scapegoats for unregulated global value chains (Acquier, Valiorgue \& Daudigeos, 2017) and receive the entire blame. Why do the charges and responsibilities tend to be concentrated on these actors?

Moreover, at the beginning of their contention movement, fringe stakeholders and their local representatives usually target various actors and implement various contention tactics (Taylor \& Van Dyke, 2004). This contention strategy is dramatically affected by the occurrence of a scandal, as fringe stakeholders tend to concentrate their contention on the stigmatised MNC. We need to understand whether the convergence process towards a single target is observable in all scandals. It is also important to understand how and to what extent fringe stakeholders and their political representatives change, adapt and develop new repertoires of actions against a stigmatised MNC: is there a specific script for contentious actions against stigmatised MNCs caught in scandals? Last, we know very little about the lasting effects of a scandal. We should also investigate further under which conditions a scandal and its effects are sustained over time.

We have underlined how publicisation is an important aspect of the process. Misconduct cannot be publicised without an agent making it known outside the boundary of local or field communities (Entman, 2012). In particular, transnational NGOs can, via a boomerang effect (Den Hond \& De Bakker, 2012), take the conflict from emerging countries to developed ones, where the reputational threat will force firms to acknowledge the consequences of their misbehaviours. Thus, the media - particularly, transnational media organisations - play a central role in constructing scandals (Lipsky, 1968; Tilly, 2008). This means that the language, symbols and metaphors that the media use to frame the conflict 
between the MNC and its fringe stakeholders are far from innocuous in the process (Bartley \& Child, 2014). However, media organisations are insufficiently studied in the literature on stakeholder politics - whereas, paradoxically, many studies show that media strategies aimed at enhancing the MNC's image and legitimacy are the most effective (McDonnell \& King, 2013). Although some works examine the dynamics of media attention (e.g., Thompson, 2000; Wiesenfeld et al., 2008), the organisational processes through which a local affair becomes a transnational publicised scandal in the media remain largely unknown (An \& Gower, 2009). The political fights between fringe stakeholders and MNCs entail the exchange of words and symbols through global media coverage (Gamson, Croteau, Hoynes, \& Sasson, 1992), and we need to decipher the organisational phenomena behind these.

The organisational contagion process we have identified raises new issues for stakeholder-politics research. Contagion means that other offenders may also be affected by the scandal. The principal question then concerns the borderline for contagion. Why do some offenders go relatively unnoticed in some cases, while criticism spreads over an entire organisational field in others? In the first situation, only the stigmatised corporation is vilified, and other offenders have an interest in remaining unconnected to the scandal (Roulet, 2015). In the second, all actors in the field must justify their practices and show to what extent they are involved in acting irresponsibly (Fligstein \& McAdam, 2011; Van Wijk et al., 2013). In some cases, contagion spreads to the customers or shareholders of the offender. However, in other cases, it affects a whole segment of the value chain that is not linked by any contractual relationship. Organisational contagion may also concern dissenters, since new and powerful NGOs may be attracted into the advocacy network and take an interest in fringe stakeholders' claims. Studying the conditions for organisational contagion and giving an account of these patterns would certainly increase our understanding of the complex and organisational dynamics of corporate scandals. 


\section{Conclusion}

In this research, we examined how scandals can facilitate the mobilisation of fringe stakeholders and their contentious actions against MNCs. We argued that the current stakeholder-politics literature emphasises agency to the detriment of structures and fails to recognise the important role played by POSs in structuring social movements. Focusing on three major social processes associated with scandals - convergence of contention towards a single target, publicisation of the deviant behaviour, and organisational contagion - we proposed that scandals create a favourable corporate political opportunity structure for fringe stakeholders by making their common cause visible and thus reducing pluralistic ignorance. This occurs through decreasing the capability of MNCs to repress such stakeholders and through helping them find allies to support their claims and provide resources. Scandals are catalysts that give considerable impetus to fringe stakeholders' contention movements by reducing the obstacles they face and by facilitating the scaling-up of these movements.

\section{REFERENCES}

Acquier, A., Valiorgue, B., \& Daudigeos, T., (2017), Sharing the shared value; a transaction cost perspective on strategic CSR policies in global value chains, Journal of Business Ethics, $144(1), 139-152$

Adut, A. (2005). A Theory of Scandal: Victorians, Homosexuality, and the Fall of Oscar Wilde. American journal of sociology, 111(1), 213-248.

Adut, A. (2008). On scandal. Cambridge: Cambridge University Press.

Adut, A. (2012). A theory of the public sphere. Sociological Theory, 30(4), 238-262.

Alexander, J. C. (1989). Structure and meaning: relinking classical sociology: Columbia University Press.

An, S.-K., \& Gower, K. K. (2009). How do the news media frame crises? A content analysis of crisis news coverage. Public Relations Review, 35(2), 107-112.

Banerjee, S. B. (2011). Voices of the Governed: towards a theory of the translocal. Organization, 18(3), 323-344.

Baron, D. P. (2001). Private politics, corporate social responsibility, and integrated strategy. Journal of Economics \& Management Strategy, 10(1), 7-45.

Baron, D. P. (2003). Private politics. Journal of Economics \& Management Strategy, 12(1), 31-66.

Bartley, T., \& Child, C. (2014). Shaming the corporation the social production of targets and the antisweatshop movement. American sociological review, 0003122414540653.

Benford, R. D., \& Snow, D. A. (2000). Framing processes and social movements: An overview and assessment. Annual review of sociology, 611-639.

Berman, S. L., Phillips, R. A., \& Wicks, A. C. (2005). Resource dependence, managerial discretion and stakeholder performance. Paper presented at the Academy of Management Proceedings. 
Böhm, S., Spicer, A., \& Fleming, P. (2008). Infra-political dimensions of resistance to international business: A Neo-Gramscian approach. Scandinavian Journal of Management, 24(3), 169-182.

Briscoe, F., Chin, M., \& Hambrick, D. C. (2014). CEO ideology as an element of the corporate opportunity structure for social activists. Academy of Management Journal, 57(6), 1786-1809.

Briscoe, F., Gupta, A., \& Anner, M. S. (2015). Social Activism and Practice Diffusion How Activist Tactics Affect Non-targeted Organizations. Administrative Science Quarterly, 0001839215579235.

Briscoe, F., \& Gupta, A. 2016. Social activism in and around organizations. Academy of Management Annals, 10(1): 671-727.

Bruijn, E., \& Whiteman, G. (2010). That which doesn't break us: Identity work by local indigenous 'stakeholders'. Journal of Business Ethics, 96(3), 479-495.

Bundy, J., \& Pfarrer, M. D. (2015). A burden of responsibility: The role of social approval at the onset of a crisis. Academy of management review, 40(3), 345-369.

Bundy, J., Shropshire, C., \& Buchholtz, A. K. (2013). Strategic cognition and issue salience: Toward an explanation of firm responsiveness to stakeholder concerns. Academy of management review, 38(3), 352-376.

Campbell, J. L. (2005). Where do we stand. Social movements and organization theory, 41-48.

Canales, R. (2010). Ari Adut: On Scandal: Moral Disturbances in Society, Politics, and Art. Administrative Science Quarterly, 55(3), 518-521.

Clarkson, M. E. (1995). A stakeholder framework for analyzing and evaluating corporate social performance. Academy of management review, 20(1), 92-117.

Clemente, Durand, R., \& Porac, J. (2016). Organizational Wrongdoing and Media Bias. In D. Palmer, R. Greenwood, \& K. Smith-Crowe (Eds.), Organizational Wrongdoing: Cambridge University Press.

Clemente, M., Durand, R., \& Roulet, T. (2017). The Recursive Nature of Institutional Change: An Annales School Perspective. Journal of Management Inquiry, 26(1), 17-31

Clemente, \& Roulet, T. (2015). Public opinion as a source of deinstitutionalization: A "spiral of silence" approach. Academy of management review, 40(1), 96-114.

Coffee, J. C. (1981). " No Soul to Damn: No Body to Kick": An Unscandalized Inquiry into the Problem of Corporate Punishment. Michigan Law Review, 79(3), 386-459.

Comyns, B., \& Franklin-Johnson, E. (2016). Corporate Reputation and Collective Crises: A Theoretical Development Using the Case of Rana Plaza. Journal of Business Ethics, 1-25.

Cottle, S. (2006). Mediatized conflict [electronic resource]: developments in media and conflict studies: McGraw-Hill International.

Daudigeos, T. (2013). In their profession's service: how staff professionals exert influence in their organization. Journal of Management Studies, 50(5), 722-749

Daudigeos, T.,Pasquier, V., Valiorgue, B., (2014), Bouc-émissaire, lynchage médiatique et contestation de la firme multinationale, Revue de l'Oragnisation Responsable, 9(2), 46-59

Davidson, W. N., Worrell, D. L., \& Lee, C. I. (1994). Stock market reactions to announced corporate illegalities. Journal of Business Ethics, 13(12), 979-987.

Davis, G., Morrill, C., Rao, H., \& Soule, S. (2008). Introduction: Social movements in organizations and markets. Administrative Science Quarterly, 53(3), 389-394.

De Bakker, F. G. (2012). Exploring networks of activism on corporate social responsibility: Suggestions for a research agenda. Creativity and Innovation Management, 21(2), 212-223.

De Bakker, F. G., \& Den Hond, F. (2008a). Introducing the Politics of Stakeholder Influence. Business \& Society, 47(1), 8-20.

De Bakker, F. G., \& Den Hond, F. (2008b). Introducing the Politics of Stakeholder Influence A Review Essay. Business \& Society, 47(1), 8-20.

De Bakker, F. G., Den Hond, F., King, B., \& Weber, K. (2013). Social movements, civil society and corporations: Taking stock and looking ahead. Organization studies, 34(5-6), 573-593.

Della Porta, D., \& Tarrow, S. G. (2005). Transnational protest and global activism: Rowman \& Littlefield Publishers.

Den Hond, F. (2009). Review essay: reflections on relationships between NGOs and corporations. Business \& Society. 
Den Hond, F., \& De Bakker, F. (2012). Boomerang politics: how transnational stakeholders impact multinational corporations in the context of globalization. In A. Lindgreen, P. Kotler, J. Vanhamme, \& F. Maon (Eds.), A Stakeholder Approach to Corporate Social Responsibility Pressures, Conflicts, Reconciliation (pp. 275-292). Aldershot: Gower Publishing.

Den Hond, F., \& De Bakker, F. G. (2007). Ideologically motivated activism: how activist groups influence corporate social change activities. Academy of management review, 32(3), 901-924.

Dorobantu, S., Henisz, W. J., \& Nartey, L. (2017). Not all sparks light a fire: Stakeholder and shareholder reactions to critical events in contested markets. Administrative Science Quarterly, 0001839216687743.

Edwards, B., \& McCarthy, J. D. (2004). Resources and social movement mobilization. The Blackwell companion to social movements, 116-152.

Eesley, C., \& Lenox, M. J. (2006). Firm responses to secondary stakeholder action. Strategic Management Journal, 27(8), 765-781.

Eisinger, P. K. (1973). The conditions of protest behavior in American cities. American political science review, 67(01), 11-28.

Entman, R. M. (2012). Scandal and silence: Media responses to presidential misconduct: Polity.

Fligstein, N., \& McAdam, D. (2011). Toward a general theory of strategic action fields. Sociological Theory, 29(1), 1-26.

Frooman, J. (1999). Stakeholder influence strategies. Academy of management review, 24(2), 191-205.

Gamson, W. A., Croteau, D., Hoynes, W., \& Sasson, T. (1992). Media images and the social construction of reality. Annual review of sociology, 373-393.

Georgallis, P. (2016). The Link Between Social Movements and Corporate Social Initiatives: Toward a Multi-level Theory. Journal of Business Ethics, 1-17.

Girard, R. (1987). Things Hidden since the Foundation of the World: Stanford University Press.

Girard, R., \& Freccero, Y. (1986). The scapegoat. Baltimore: Johns Hopkins University Press

Girard, R., Gifford, P., \& Dupuy, J.-P. (2006). Generative scapegoating. Contagion, 12, 13.

Givan, R. K., Roberts, K. M., \& Soule, S. A. (2010). The diffusion of social movements: Actors, mechanisms, and political effects: Cambridge University Press.

Glenn, J. K., \& Mendelson, S. (2002). The Power and Limits of NGOs: New York: Columbia University Press.

Graffin, S. D., Bundy, J., Porac, J. F., Wade, J. B., \& Quinn, D. P. (2013). Falls from Grace and the Hazards of High Status The 2009 British MP Expense Scandal and Its Impact on Parliamentary Elites. Administrative Science Quarterly, 58(3), 313-345.

Greve, H. R., Palmer, D., \& Pozner, J. E. (2010). Organizations gone wild: The causes, processes, and consequences of organizational misconduct. The Academy of Management Annals, 4(1), 53107.

Hart, S. L., \& Sharma, S. (2004). Engaging fringe stakeholders for competitive imagination. The Academy of Management Executive (1993-2005), 7-18.

Herepath, A., \& Kitchener, M. (2016). When small bandages fail: the field-level repair of severe and protracted institutional breaches. Organization Studies, 0170840615622065.

Hoque, M., Noe Cross, J., \& Kunkel, R. A. (2012). Andersen implosion over Enron: an analysis of the contagion effect on Fortune 500 firms. Managerial Finance, 38(7), 678-688.

Hudson, B. A. (2008). Against all odds: A consideration of core-stigmatized organizations. Academy of management review, 33(1), 252-266.

Jackson, G., Brammer, S., Karpoff, J. M., Lange, D., Zavyalova, A., Harrington, B., . . . Deephouse, D. L. (2014). Grey areas: irresponsible corporations and reputational dynamics. Socio-Economic Review, 12(1), 153-218.

Jenkins, J. C., \& Perrow, C. (1977). Insurgency of the powerless: Farm worker movements (19461972). American Sociological Review, 42: 249-267.

Jensen. (2006). Should we stay or should we go? Accountability, status anxiety, and client defections. Administrative Science Quarterly, 51(1), 97-128.

Jensen, T., \& Sandström, J. (2011). Stakeholder theory and globalization: The challenges of power and responsibility. Organization studies, 32(4), 473-488. 
Jonsson, S., Greve, H. R., \& Fujiwara-Greve, T. (2009). Undeserved loss: The spread of legitimacy loss to innocent organizations in response to reported corporate deviance. Administrative Science Quarterly, 54(2), 195-228.

Jordan, L., \& Van Tuijl, P. (2000). Political responsibility in transnational NGO advocacy. World Development, 28(12), 2051-2065.

Keck, M. E., \& Sikkink, K. (1998). Activists beyond borders: Advocacy networks in international politics. Cambridge: Cambridge University Press.

Kepplinger, H. M., Geiss, S., \& Siebert, S. (2012). Framing scandals: Cognitive and emotional media effects. Journal of Communication, 62(4), 659-681.

Khan, F. R., Munir, K. A., \& Willmott, H. (2007). A dark side of institutional entrepreneurship: Soccer balls, child labour and postcolonial impoverishment. Organization studies, 28(7), 1055-1077.

King, B. G. (2007). A social movement perspective of stakeholder collective action and influence. Business \& Society.

King, B. G. (2008). A political mediation model of corporate response to social movement activism. Administrative Science Quarterly, 53(3), 395-421.

King, B. G., \& Pearce, N. A. (2010). The contentiousness of markets: Politics, social movements, and institutional change in markets. Annual review of Sociology, 36, 249-267.

Kraemer, R., Whiteman, G., \& Banerjee, B. (2013). Conflict and astroturfing in Niyamgiri: The importance of national advocacy networks in anti-corporate social movements. Organization studies, 34(5-6), 823-852.

Kriesi, H. (2004). Political context and opportunity. The Blackwell companion to social movements, 67-90.

Lipsky, M. (1968). Protest as a political resource. The American Political Science Review, 62(4), $1144-1158$.

McAdam, D., McCarthy, J. D., \& Zald, M. N. (1996). Comparative perspectives on social movements: Political opportunities, mobilizing structures, and cultural framings. Cambridge: Cambridge University Press.

McAdam, D., Tarrow, S., \& Tilly, C. (2003). Dynamics of contention. Social Movement Studies, 2(1), 99-102.

McAteer, E., \& Pulver, S. (2009). The corporate boomerang: Shareholder transnational advocacy networks targeting oil companies in the Ecuadorian Amazon. Global Environmental Politics, 9(1), 1-30.

McDonnell, M.-H., \& King, B. (2013). Keeping up appearances reputational threat and impression management after social movement boycotts. Administrative Science Quarterly, 58(3), 387419.

McDonnell, M.-H., King, B. G., \& Soule, S. A. (2015). A dynamic process model of private politics activist targeting and corporate receptivity to social challenges. American sociological review, $80(3), 654-678$.

Mena, S., \& Palazzo, G. (2012). Input and output legitimacy of multi-stakeholder initiatives. Business Ethics Quarterly, 22(3), 527-556.

Mena, S., Rintamäki, J., Fleming, P., \& Spicer, A. (2016). On the forgetting of corporate irresponsibility. Academy of Management Review, 41(4), 720-738.

Mena, S., \& Waeger, D. (2014). Activism for corporate responsibility: Conceptualizing private regulation opportunity structures. Journal of Management Studies, 51(7), 1091-1117.

Meyer, D. S. (2004). Protest and political opportunities. Annual review of sociology, 125-145.

Mitchell, R. K., Agle, B. R., \& Wood, D. J. (1997). Toward a theory of stakeholder identification and salience: Defining the principle of who and what really counts. Academy of management review, 22(4), 853-886.

Ocasio, W. (1997). Towards an attention-based view of the firm. Strategic management journal, 187206.

Olson, M. (2009). The logic of collective action. Harvard University Press.

Palmer, D. (2012). Normal organizational wrongdoing: A critical analysis of theories of misconduct in and by organizations: Oxford University Press on Demand.

Poerksen, B., \& Detel, H. (2014). The unleashed scandal: the end of control in the digital age: Imprint Academic. 
Pontikes, E., Negro, G., \& Rao, H. (2010). Stained Red A Study of Stigma by Association to Blacklisted Artists during the "Red Scare" in Hollywood, 1945 to 1960. American sociological review, 75(3), 456-478.

Reinecke, J., \& Donaghey, J. (2015). After Rana Plaza: Building coalitional power for labour rights between unions and (consumption-based) social movement organisations. Organization, 22(5), 720-740.

Rodrigues, M. G. (2011). Rethinking the impact of transnational advocacy networks. New Global Studies, 5, 1-21.

Roulet, T. J. (2015). "What good is Wall Street?" Institutional contradiction and the diffusion of the stigma over the finance industry. Journal of Business Ethics, 130(2), 389-402.

Roulet, T. J. (2017). Good to Be Disliked? Exploring the Relationship Between Disapproval of Organizations and Job Satisfaction in the French Context. Journal of General Management. 42(4), 68-79

Rowley, T. I., \& Moldoveanu, M. (2003). When will stakeholder groups act? An interest and identity based model of stakeholder group mobilization. Academy of management review, 28(2), 204219.

Rucht, D. (2004). Movement allies, adversaries, and third parties. The Blackwell companion to social movements, 197-216.

Sass, J., \& Crosbie, T. (2013). Democracy and scandal: A research agenda. Comparative Sociology, 12(6), 851-862.

Schultz, F., Kleinnijenhuis, J., Oegema, D., Utz, S., \& Van Atteveldt, W. (2012). Strategic framing in the BP crisis: A semantic network analysis of associative frames. Public Relations Review, 38(1), 97-107.

Shah, D. V., Watts, M. D., Domke, D., \& Fan, D. P. (2002). News framing and cueing of issue regimes: Explaining Clinton's public approval in spite of scandal. Public Opinion Quarterly, 66(3), 339-370.

Shymko, Y., \& Roulet, T. J. (2017). When Does Medici Hurt Da Vinci? Mitigating the Signaling Effect of Extraneous Stakeholder Relationships in the Field of Cultural Production. Academy of Management Journal, 60(4), 1307-1338.

Siddiqui, J., \& Uddin, S. (2016). Human rights disasters, corporate accountability and the state: Lessons learned from Rana Plaza. Accounting, Auditing \& Accountability Journal, 29(4), 679704.

Smith, J. G., Chatfield, C., \& Pagnucco, R. (1997). Transnational social movements and global politics: Solidarity beyond the state: Syracuse University Press.

Soule. (2009). Contention and corporate social responsibility: Cambridge University Press.

Soule. (2012a). Social movements and markets, industries, and firms. Organization studies, 33(12), $1715-1733$.

Soule. (2012b). Targeting organizations: Private and contentious politics. Research in the Sociology of Organizations, 34, 261-285.

Soule. (2013). Diffusion and scale shift. The Wiley-Blackwell Encyclopedia of Social and Political Movements.

Sutherland, N., Land, C., \& Böhm, S. (2014). Anti-leaders (hip) in Social Movement Organizations: The case of autonomous grassroots groups. Organization, 21(6), 759-781.

Tarrow, S. (1994). Power in movement: Social movements, collective action and mass politics in the modern state: Cambridge: Cambridge University Press.

Tarrow, S. (1998). Fishnets, internets, and catnets: Globalization and transnational collective action. Challenging authority: The historical study of contentious politics, 228-244.

Tarrow, S. (2005). The new transnational activism. Cambridge: Cambridge University Press.

Taylor, V., \& Van Dyke, N. (2004). 'Get up, stand up': Tactical repertoires of social movements. The Blackwell companion to social movements, 262-293.

Thompson, J. B. (2000). Political Scandal. Power and Visibility in the Media Age. Cambridge: Polity Press.

Tilly, C. (2008). Contentious performances. New York: Cambridge University Press Cambridge.

Tilly, C., \& Tarrow, S. (2006). Contentious politics. Oxford: Oxford University Press. 
Van Der Heijden, H.-A. (2006). Globalization, environmental movements, and international political opportunity structures. Organization \& Environment, 19(1), 28-45.

Van Wijk, J., Stam, W., Elfring, T., Zietsma, C., \& Den Hond, F. (2013). Activists and incumbents tying for change: The interplay of agency, culture and networks in field evolution. Academy of Management Journal, 55(2).

Vasi, I. B., \& King, B. G. (2012). Social Movements, Risk Perceptions, and Economic Outcomes The Effect of Primary and Secondary Stakeholder Activism on Firms' Perceived Environmental Risk and Financial Performance. American sociological review, 77(4), 573-596.

Weber, K., \& Waeger, D. (2017). Organizations As Polities: An Open Systems Perspective. Academy of Management Annals: annals. 2015.0152.

Wiesenfeld, B. M., Wurthmann, K. A., \& Hambrick, D. C. (2008). The stigmatization and devaluation of elites associated with corporate failures: A process model. Academy of management review, 33(1), 231-251.

Yaziji, M., \& Doh, J. P. (2013). The role of ideological radicalism and resource homogeneity in social movement organization campaigns against corporations. Organization studies, 34(5-6), 755780.

Yu, X. (2009). From passive beneficiary to active stakeholder: Workers' participation in CSR movement against labor abuses. Journal of Business Ethics, 87, 233-249.

Yue, L. Q., Rao, H., \& Ingram, P. (2013). Information spillovers from protests against corporations: A tale of Walmart and Target. Administrative Science Quarterly, 58(4), 669-701.

Zhang, J., \& Luo, X. R. (2013). Dared to care: Organizational vulnerability, institutional logics, and MNCs' social responsiveness in emerging markets. Organization Science, 24(6), 1742-1764

Zietsma, C., \& Winn, M. I. (2008). Building Chains and Directing Flows Strategies and Tactics of Mutual Influence in Stakeholder Conflicts. Business \& Society, 47(1), 68-101 


\section{TABLE AND FIGURES}

Table 1: Dimensions of POSs

\begin{tabular}{|c|c|c|c|}
\hline Dimension & Definition & Range & Examples \\
\hline Openness & $\begin{array}{l}\text { Allowing contending } \\
\text { actors to participate in } \\
\text { decision-making } \\
\text { processes }\end{array}$ & $\begin{array}{l}\text { Open to } \\
\text { closed }\end{array}$ & $\begin{array}{l}\text { Voting systems, presence in } \\
\text { assembly, inclusion of } \\
\text { representatives }\end{array}$ \\
\hline Presence of allies & $\begin{array}{l}\text { Finding support for } \\
\text { contending actors' claims } \\
\text { in decision-making } \\
\text { processes by elites }\end{array}$ & $\begin{array}{l}\text { Integrative } \\
\text { to exclusive }\end{array}$ & $\begin{array}{c}\text { Transparency, expression of } \\
\text { differences, sensibility of } \\
\text { elites }\end{array}$ \\
\hline $\begin{array}{l}\text { Repression } \\
\text { capability }\end{array}$ & $\begin{array}{l}\text { Capacity of the targeted } \\
\text { actor to repress and to } \\
\text { sanction contending } \\
\text { actors } \\
\end{array}$ & $\begin{array}{l}\text { Weak to } \\
\text { strong }\end{array}$ & $\begin{array}{l}\text { Retaliation measures, police } \\
\text { mobilisation, sanctions }\end{array}$ \\
\hline $\begin{array}{l}\text { Implementation } \\
\text { of outcomes }\end{array}$ & $\begin{array}{l}\text { Capacity to enforce and } \\
\text { monitor decisions }\end{array}$ & $\begin{array}{l}\text { Weak to } \\
\text { strong }\end{array}$ & $\begin{array}{l}\text { Verification procedures, } \\
\text { reporting requirements, } \\
\text { monitoring organisations }\end{array}$ \\
\hline
\end{tabular}

Table 2: Applications of the dimensions of POSs to corporate POSs

\begin{tabular}{ccc} 
Dimension & $\begin{array}{c}\text { Application to corporate } \\
\text { opportunity structures }\end{array}$ & Examples \\
\hline \hline Openness & $\begin{array}{c}\text { Inclusion of stakeholders in the } \\
\text { design, implementation or } \\
\text { assessment of the corporate } \\
\text { strategy }\end{array}$ & $\begin{array}{c}\text { Sustainability reports, } \\
\text { involvement of activists in the } \\
\text { board, openness to minority } \\
\text { shareholders }\end{array}$ \\
\hline $\begin{array}{c}\text { Presence of } \\
\text { allies }\end{array}$ & $\begin{array}{c}\text { Finding support for contending } \\
\text { actors' claims within the } \\
\text { companies, with employees } \\
\text { and managers lobbying in } \\
\text { favour of the activists' claims }\end{array}$ & $\begin{array}{c}\text { Corporate volunteering and trade } \\
\text { unions provide a bridge with }\end{array}$ \\
$\begin{array}{c}\text { ontside activists } \\
\text { Ideology }\end{array}$ & $\begin{array}{c}\text { Political orientation, values and } \\
\text { beliefs of the firm }\end{array}$ & $\begin{array}{c}\text { Political orientation of the CEO, } \\
\text { objective of the firm, } \\
\text { organisational culture }\end{array}$ \\
\hline $\begin{array}{c}\text { Repression } \\
\text { capability }\end{array}$ & $\begin{array}{c}\text { Capacity of the firm to repress } \\
\text { contending actors either by } \\
\text { internal or external means }\end{array}$ & $\begin{array}{c}\text { Lobbying, retaliation measures, } \\
\text { use of private militia or local } \\
\text { police to pressure contending } \\
\text { stakeholders }\end{array}$ \\
\hline $\begin{array}{c}\text { Implementation } \\
\text { of outcomes }\end{array}$ & $\begin{array}{c}\text { Internal audits and project } \\
\text { management to correct } \\
\text { operations and behaviour and }\end{array}$ & $\begin{array}{c}\text { Internal audit, procedures, } \\
\text { reporting internal or industry } \\
\text { requirements and monitoring }\end{array}$ \\
\hline
\end{tabular}


monitor progress. 